\title{
Interest rate spreads in the eurozone: Fundamentals or sentiments?
}

\author{
Maximilian Gödl ${ }^{1} \cdot$ Jörn Kleinert ${ }^{1}$
}

(C) The Author(s) 2016. This article is published with open access at Springerlink.com

\begin{abstract}
We analyze the determinants of interest rates on long-term government bonds within the eurozone to assess whether the recent divergence in interest rates is attributable to changes in common economic fundamentals. First, we argue that the panel regression approach commonly employed in existing literature has conceptual as well as empirical problems. Therefore we take an event study approach using high-frequency (daily) data to investigate the impact of three categories of news events on eurozone bond yields. Our results indicate that yields react to news on key economic indicators such as growth and budget deficit forecasts. By contrast, we do not find evidence that investors react to announcements of fiscal bailouts or austerity measures.
\end{abstract}

Keywords Interest spreads · Public debt · Event study

JEL Classification $\mathrm{G} 12 \cdot \mathrm{G} 14 \cdot \mathrm{H} 63$

\section{Introduction}

In the aftermath of the global financial crisis of 2008, interest rates on government bonds began to diverge dramatically within the eurozone after they had been converging in the decade before. While some governments (like the German government) are now able to borrow at record low interest rates, governments from

Jörn Kleinert

joern.kleinert@uni-graz.at

Maximilian Gödl

maximilian.goedl@uni-graz.at

1 University of Graz, Universitätsstraße 15, Graz, Austria 
other countries (Greece, Ireland, Italy, Portugal, and Spain) experienced a sharp and sudden increase in their borrowing costs bringing them to (and, in the case of Greece, beyond) the brink of default. The eurozone governments together with the International Monetary Fund (IMF) responded to this crisis with extensive loans to the troubled governments conditional on a set of fiscal and structural reforms. ${ }^{1}$ The primary goal of these reforms is to rebuild the confidence of creditors in the solvency of the governments by reducing the public debt relative to GDP and to enhance the overall productive potential of the economy. This policy rests on the proposition that the crisis was caused by a deterioration in the fundamental determinants of public sector solvency and that it can be solved only by improving these fundamentals.

However, this proposition is cast into doubt by two observations: (1) some of the crisis countries did not feature "bad fundamentals" prior to 2008. Ireland and Spain, in particular, had debt-to-GDP ratios below the eurozone average and were even running primary budget surpluses before 2009. (2) Some countries outside the monetary union that had equally bad fundamentals did not experience a debt crisis. The United Kingdom as well as the United States both have debt levels comparable to the eurozone crisis countries and yet continue to borrow at much lower interest rates.

The last point has been made most forcefully by De Grauwe (2012), who argues that the eurozone debt crisis was caused by a self-fulfilling shift in investor sentiments resulting in a run on eurozone government debt. Such a run, De Grauwe argues, is more likely to occur in a monetary union, in which governments cannot rely on their national central banks to act as lenders of last resort. Corsetti and Dedola (2013) underpinned this point by a more rigorous model analysis. Recent work by De Grauwe and Ji (2013) has sought to verify this alternative explanation of the eurozone debt crisis empirically. More generally, the above observations raise the question whether and to what extent government bond yields are driven by fundamentals as opposed to market sentiments.

Before answering this question, one first needs to clarify what the fundamental determinants of government solvency are. In the existing empirical studies on the determinants of government bond yields, it is customary to explain the yield spreads by measures of public sector solvency like the debt-to-GDP ratio, as well as measures of 'macroeconomic vulnerability' such as the current account balance or the size of the banking sector. The choice of explanatory variables is usually not derived from an explicit theoretical model. This paper starts from the well-known intertemporal budget constraint of the government to single out those variables that determine government yield spreads. Using the insights from this theoretical discussion we study the determinants of (long-term) government bond yields of European countries.

The existing literature on the issue has relied mainly on panel regression frameworks with low frequency (usually quarterly) data. However, this approach

\footnotetext{
$\overline{1}$ Such "bailout packages" were given to Greece in March 2010, to Ireland in November 2010, to Portugal in May 2011, and to Cyprus in 2013. Spain and Italy engaged in similar reforms, but did not receive direct loans from other governments.
} 
has a number of econometric problems which we discuss in the paper. Most importantly, we doubt that the effects of the explanatory variables of the countries analyzed are homogenous enough to be studied in a panel framework. We therefore employ a random coefficients model using quarterly data for 17 European countries, which allows us to test whether the poolability assumption underlying the panel approach is warranted for our sample.

In a second step we look at high-frequency (daily) data to shed more light on the determinants of government borrowing costs. However, the use of daily interest rate data makes a regression approach infeasible, because the required explanatory variables are not observed at this frequency. Hence we rely on event study techniques to investigate what kind of economic and financial market news have a significant impact on government interest rates. We focus on three categories of news, which we interpret as news about underlying fundamentals of public sector solvency: official macroeconomic forecasts, the announcement of intra-governmental fiscal assistance measures and the announcements of fiscal reforms ("austerity packages"). In so far as these news events contain new information on fundamentals for investors, we expect them to change interest rates significantly. A lack of reaction to news thus suggests that interest rates are indeed unrelated to fundamentals.

The remainder of the paper is in four sections. The next section looks at the intertemporal budget constraint of the government to derive the fundamentals of government bond yields which we use in our empirical investigation. Section 3 reports and discusses the results of our random coefficient estimation. In Sect. 4, we turn to daily data and conduct the event study. The final section summarizes the main results of the paper.

\section{The fundamental determinants of government borrowing costs}

Differences in government bond yields result from the differences in the perceived riskiness of these bonds. In general, this risk contains a default risk element as well as a liquidity risk and an exchange rate risk element. For interest spreads within the eurozone, the exchange rate risk element is, of course, absent. Thus one can expect the default risk to dominate as a determining factor of within-EMU spreads. Default risk is in turn determined by the government's future ability (and willingness) to service its debt and by the loss to investors given default. The central tool to evaluate the government's future solvency is the intertemporal budget constraint. Let $D_{t}$ denote gross real government debt at time $t, P S_{t}$ the primary government budget balance (non-interest government revenues minus non-interest government expenditures) and $r_{t}$ the real interest rate on government debt maturing at $t$. Government debt evolves according to:

$$
D_{t+1}=D_{t}\left(1+r_{t}\right)-P S_{t} .
$$


Iterating $T$ periods forward yields

$$
D_{t}=E_{t}\left[\sum_{s=0}^{T} \frac{P S_{t+s}}{\prod_{k=0}^{s-1}\left(1+r_{t+k}\right)}+\frac{D_{t+T}}{\left(1+r_{t+T-1}\right)}\right]
$$

Here $E_{t}$ denotes the expectation operator conditional on information available at time $t$. We now impose the familiar "transversality condition"

$$
\lim _{T \rightarrow \infty} E_{t}\left[\frac{D_{t+T}}{\left(1+r_{t+T-1)}\right.}\right]=0 .
$$

This condition rules out 'bubbles' in the government bond market. Combining (2) and (3) results in the well-known intertemporal government budget constraint:

$$
D_{t}=E_{t}\left[\sum_{s=0}^{\infty} \frac{P S_{t+s}}{\prod_{k=0}^{s-1}\left(1+r_{t+k}\right)}\right]
$$

A violation of the intertemporal budget constraint implies an infinitely exploding debt level and thus a fundamental insolvency of the government. It is instructive to look at (4) in a non-stochastic steady state where the real interest rate is constant $\left(r_{t}=r\right.$ for all $\left.t\right)$ and real GDP grows at a constant (exogenous) rate $g$. A stable debtto-GDP ratio for a government with primary surplus growing proportionally to the GDP with rate $g$ is given by

$$
\frac{D}{Y}=\frac{1}{r-g} \frac{P S}{Y} .
$$

In this equation, $r$ must be interpreted to be the risk-free real interest rate. The equation can be read in two ways. For a given risk-free interest rate and given real GDP growth rate, it defines the necessary primary surplus (relative to GDP) that exactly stabilizes a given debt-to-GDP ratio. Alternatively, it defines a sustainable (i.e. non-exploding) debt-to-GDP ratio for given primary surplus, risk-free interest rate and growth rate. Equation (5) is not a sufficient condition for a sustainable debtto-GDP ratio in the sense that it rules out a government default. It merely defines combinations of debt and primary surplus levels which are consistent with a constant debt-to-GDP ratio.

Equation (5) may thus be used as an indicator for long-run public sector solvency since a violation of (5) makes a government default more likely. The probability of default increases with the debt-to-GDP ratio, decreases with rising primary surplus (as a share of GDP) and decreases with a rising real growth rate. A higher probability of default induces a higher risk premium on government bonds.

Thus, the sovereign risk premium depends on the debt-to-GDP ratio, the expected growth rate and the expected primary budget surplus. We use the spread of the interest rate on government bonds of a particular country over the interest rate on the corresponding German bonds as our measure of the country-specific risk premium. We can do this because the German government debt is generally considered to be risk-free. In the empirical analysis, we therefore explain the 
government bond yield spread of a country by the fundamentals from the intertemporal budget constraints: the debt-to-GDP ratio, the growth rate of real GDP, and the primary surplus as a share of GDP.

These are also the most commonly used variables in the existing literature assessing the effects of changes in the fundamentals on interest rate spreads or credit default swap (CDS) spreads. These papers differ in (1) the endogenous variable which is bond yield spreads (e.g., Attinasi et al. 2011; Gerlach et al. 2010; De Grauwe and Ji 2013; Steinkamp and Westermann 2014) or CDS spreads (Aizenman et al. 2013), (2) the main explanatory variable which is "fiscal space" (Aizenman et al. 2013), the debt-GDP ratio (De Grauwe and Ji 2013), the size of the banking sector (Gerlach et al. 2010), announcements of bank rescue packages (Attinasi et al. 2011), or the share of liabilities held by senior creditors (Steinkamp and Westermann 2014), and (3) the econometric method employed, which is fixed effect panel estimation (De Grauwe and Ji 2013; Steinkamp and Westermann 2014), dynamic panel estimation (Attinasi et al. 2011; Aizenman et al. 2013) or a random coefficients model (Gerlach et al. 2010).

The paper that comes closest to our approach of choosing explanatory variables is Beirne and Fratzscher (2013) who also start from the government's intertemporal budget constraint. Based on panel regressions, they find that the increase of interest rate spreads in the eurozone can be explained by a combination of deteriorating fundamentals and an increased sensitivity of investors for these fundamentals. We believe that their analysis suffers from the problems we find with the panel approach.

In addition to the fundamental fiscal variables, measures for the liquidity of the bond market are proposed in the literature. While liquidity measures have been found significant in determining government bond yield spreads in Beber et al. (2009), we refrain from using them, because they are either (endogenous) price measures or just another variable expressing total government debt. Global risk factors are also excluded because they cancel out when bond yields of a country are measured relative to the German bond yield.

One risk factor, however, should be addressed: exchange rate revaluation risk. ${ }^{2}$ Not controlling for expected exchange rate changes in the regression could lead to biased estimates for our sample of non-eurozone countries. While we are aware of this potential problem, we do not find the solutions offered in the existing literature satisfactory. For instance, De Grauwe and Ji (2013) use the real effective exchange rate to control for changes in price competitiveness. By excluding depreciation expectations we are implicitly assuming that investors expect the exchange rate to be unchanged in the future. This assumption can be justified by the Meese and Rogoff (1983) result that the exchange rate follows a random walk over short horizons (up to 12 months).

Therefore we estimate an econometric model of government bond yield spreads relative to German bonds including the debt-to-GDP ratio, the primary budget deficit, and real GDP growth as explanatory variables. ${ }^{3}$ We estimate panel models

\footnotetext{
${ }^{2}$ We are grateful to a referee for pointing this out.

3 We use contemporaneous variables because at the particular time expected future values are not available at quarterly basis. We checked with forecast from the World Economic Outlook which reduced the number of observations by half because there are only two WEO forecast per year. the results are less robust but in line with the results presented in the paper.
} 
for the 17 countries in our sample but, in contrast to much of the literature, allowing for country-specific slope coefficients. This set-up enables us to assess which countries are homogenous enough to be grouped to a panel analysis.

\section{Evidence from quarterly data}

Our sample comprises 17 European countries, of which 10 (Austria, Belgium, Finland, France, Greece, Ireland, Italy, the Netherlands, Portugal, Spain) are members of the eurozone and seven are not (the Czech Republic, Denmark, Hungary, Norway, Poland, Sweden, the United Kingdom). We excluded all European countries which have changed their currency regime after 2001. For included countries we obtained interest rates on 10-year benchmark bonds reported by the European Central Bank (ECB) on a quarterly basis. ${ }^{4}$ Data on gross public debt, gross domestic product, primary government budget deficits come from Eurostat and are observed from the 1st quarter 2001 up to the 1st quarter 2013. "Appendix 1" contains a detailed description of our data.

The countries in the sample differ greatly with respect to the spread of the interest rate paid on their 10-years government bond over the German government bond benchmark. Figure 1 shows the time series of benchmark bond yields for four subsamples: eurozone non-crisis countries seen in (a), eurozone crisis countries seen in (b), and non-eurozone old-EU countries seen in (c), and non-eurozone new accession countries in $(\mathrm{d})$.

Our basic econometric model uses a set of "fundamentals" to explain the spread of national interest rates over the German benchmark rate. The choice of fundamentals is guided by the theoretical considerations from the last section. We start with panel mean-group estimations which allow for heterogeneity among different countries in their estimated coefficients. Mean-group estimators are designed for 'moderate- $\mathrm{T}$, moderate- $\mathrm{N}$ ' macro panels as ours, where moderate typically means from around 15 time-series/cross-section observations. The procedure has two steps: (1) the estimation of a group-specific regression and (2) averaging the estimated coefficients across groups.

In this set-up, the slope parameters need not be homogeneous across countries (i.e. for all $i, \beta_{i 0}=\beta_{0}, \beta_{i 1}=\beta_{1}$ etc. is not required). For each country $i$, the regression equation is

$$
\operatorname{spread}_{i t}=\beta_{i 0}+\beta_{i 1} \text { debt }_{i t}+\beta_{i 2} \text { growth }_{i t}+\beta_{i 3} \text { deficit }_{i t}+\epsilon_{i t},
$$

where debt is the government debt in percent of GDP, growth is the growth rate of real GDP, and deficit is the primary government budget deficit in percent of GDP. $\epsilon_{i t}$ is a zero-mean error. The estimated coefficients are averaged and shown in Table 1. The first column shows the results for the entire sample. We estimate a positive and significant coefficient on debt and a negative and significant coefficient on growth, which is what we would expect from our theoretical discussion. The coefficient on

\footnotetext{
${ }^{4}$ Not all governments actually issue bonds with 10-year maturity. Therefore, the ECB calculates reference yields using government bonds with maturities close to 10 years.
} 


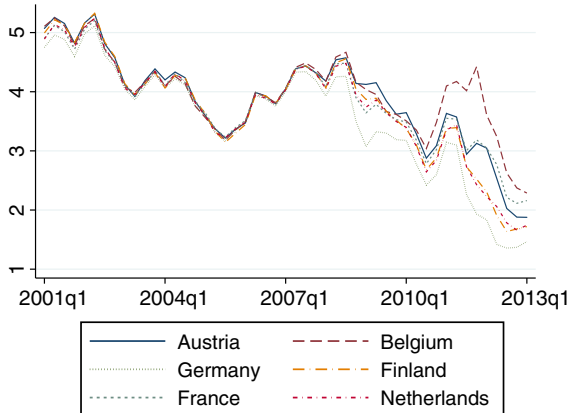

(a)

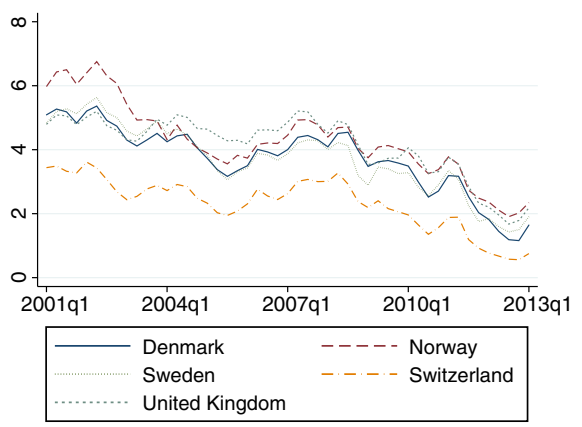

(c)

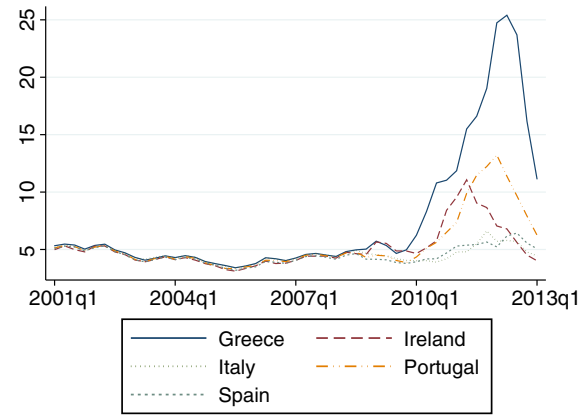

(b)

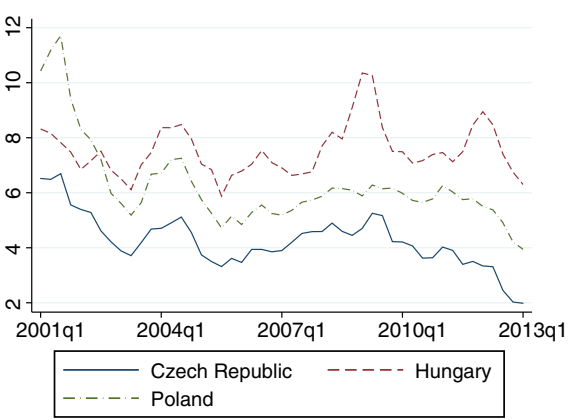

(d)

Fig. 1 Government bond yield spreads over Germany. a Eurozone non-crisis countries. b Eurozone crisis countries. c Non-eurozone old-EU countries. d Non-eurozone accession countries

deficit is negative but only significant at the $10 \%$ level. These results are similar to fixed effects estimations (which are not presented) and also broadly in line with those of De Grauwe and Ji (2013).

The columns in Table 1 show results for the whole sample and four sub-samples: eurozone countries only, non-eurozone (or "stand-alone") countries, eurozone crisis countries, and eurozone non-crisis countries. There is considerable variation in the estimated parameters and their significance that cast doubts on the informative value of the full sample estimates. In fact, the results obtained with the full sample seem to be driven to a large extent by the eurozone crisis countries. While the signs are similar, the size of the effects differs by a magnitude of ten and more. The "eurozone crisis countries" and the "eurozone non-crisis countries" subsamples are best comparable because all member countries share the same currency. The two panel estimations reveal large differences in the size of the effects of the determinants of the risk premium. The results for the non-eurozone countries should be interpreted with caution since exchange rate expectations are not controlled for.

Looking at the large differences of the coefficients between the groups, it is worth checking whether the coefficients of the subsamples have more informative value. 
Table 1 Panel regression, mean group estimator

\begin{tabular}{llllll}
\hline & $\begin{array}{l}\text { All } \\
\text { countries }\end{array}$ & $\begin{array}{l}\text { Eurozone } \\
\text { countries }\end{array}$ & $\begin{array}{l}\text { Non-eurozone } \\
\text { countries }\end{array}$ & $\begin{array}{l}\text { Eurozone crisis } \\
\text { countries }\end{array}$ & $\begin{array}{l}\text { Eurozone non-crisis } \\
\text { countries }\end{array}$ \\
\hline Debt & $0.025^{* *}$ & $0.054^{* *}$ & 0.003 & $0.126^{* * *}$ & $0.018^{* * *}$ \\
Growth & $(0.012)$ & $(0.026)$ & $(0.012)$ & $(0.031)$ & $(0.006)$ \\
& $-0.036^{* *}$ & $-0.034^{* * *}$ & -0.072 & -0.022 & $-0.035^{* * *}$ \\
Deficit & $(0.016)$ & $(.012)$ & $(0.045)$ & $(0.105)$ & $(-0.009)$ \\
& $0.039 *$ & -0.004 & 0.031 & -0.236 & 0.023 \\
Constant & $(0.024)$ & $(0.089)$ & $(0.029)$ & $(0.180)$ & $(0.039)$ \\
& -0.383 & $-1.673 * *$ & 0.914 & -9.477 & $-0.933 * *$ \\
Observations & 833 & 490 & $(0.781)$ & $(4.180)$ & $(0.474)$ \\
Groups & 17 & 10 & 343 & 245 & 245 \\
\hline
\end{tabular}

Dependent variable: 10 year interest spread over Germany

Robust standard errors in parentheses

$*, * *, * * *$ Significance at the level of 10,5 , and $1 \%$, respectively

We therefore report the first stage of the mean group panel estimator and look at the parameters $\beta_{i 0}, \beta_{i 1}, \ldots$ differences across countries.

Table 2 provides the results from the first stage estimation for all countries in the sample. The general picture emerging from this regression is quite clear: the estimated slope parameters differ substantially between countries. While the signs of the coefficients are widely in line, their sizes and statistical significance differ greatly. These results indicate that the impact of fundamentals on government bond yields is very inhomogeneous and that there is no tight relationship between fundamentals and spreads except for those countries that actually experienced a crisis. For Greece, Ireland, Italy, Spain and Portugal, debt has a fairly strong and highly significant positive effect on the spread. For the other eurozone countries as well as for the non-eurozone countries, the estimated debt parameters are much smaller, vary in sign and are not always significant.

The effect of real GDP growth is even more heterogeneous across countries. Higher growth rates are not generally associated with significantly lower spreads. In the case of Ireland and Portugal, this finding can be explained by the fact that the rise in the spreads occurred after the recession of 2009/10 reached its trough and the economy was already starting to recover. The estimated parameters on primary deficits are rather puzzling at first glance. For some countries, including the crisiscountries Ireland and Spain, primary deficits seem to have a negative impact on borrowing costs. The explanation for this seemingly perverse result is that by the time the Greek and Irish spreads started to rise in 2010, the government's primary balance was actually improving, whereas during the years before the crisis, the spreads where very low and the primary balance was modestly negative in the case of Greece and modestly positive in the case of Ireland. For most of the other countries, the estimated primary deficit parameters have the expected (positive) 
Table 2 Mean group panel estimator, first stage

\begin{tabular}{|c|c|c|c|c|}
\hline & Debt & Growth & Deficit & Constant \\
\hline Austria & $\begin{array}{l}0.028^{* * *} \\
(0.010)\end{array}$ & $\begin{array}{c}-0.061 * * * \\
(0.016)\end{array}$ & $\begin{array}{l}0.051 * * * \\
(0.031)\end{array}$ & $\begin{array}{c}-1.520^{* * *} \\
(0.677)\end{array}$ \\
\hline Belgium & $\begin{array}{l}0.020 * * \\
(0.009)\end{array}$ & $\begin{array}{r}-0.014 \\
(.035)\end{array}$ & $\begin{array}{l}0.173 * * * \\
(0.026)\end{array}$ & $\begin{array}{c}-1.164 * * \\
(0.879)\end{array}$ \\
\hline Finland & $\begin{array}{c}0.0003 \\
(0.004)\end{array}$ & $\begin{array}{c}-0.026 * * * \\
(0.006)\end{array}$ & $\begin{array}{c}-0.019 * * \\
(0.009)\end{array}$ & $\begin{array}{c}0.270 \\
(0.197)\end{array}$ \\
\hline France & $\begin{array}{l}0.028 * * * \\
(0.003)\end{array}$ & $\begin{array}{c}-0.045^{* * *} \\
(0.016)\end{array}$ & $\begin{array}{c}-0.047 \\
(0.022)\end{array}$ & $\begin{array}{c}-1.581^{* * *} \\
(0.203)\end{array}$ \\
\hline Netherlands & $\begin{array}{l}0.010^{* * *} \\
(0.003)\end{array}$ & $\begin{array}{c}-0.029 * * * \\
(0.009)\end{array}$ & $\begin{array}{c}0.009 \\
(0.011)\end{array}$ & $\begin{array}{c}-0.358 * \\
(0.190)\end{array}$ \\
\hline Greece & $\begin{array}{l}0.215^{* * *} \\
(0.053)\end{array}$ & $\begin{array}{r}-0.413 \\
(0.257)\end{array}$ & $\begin{array}{c}-0.547 * * \\
(0.254)\end{array}$ & $\begin{array}{c}-19.506^{* * *} \\
(6.454)\end{array}$ \\
\hline Ireland & $\begin{array}{l}0.050 \text { *** } \\
(0.006)\end{array}$ & $\begin{array}{l}0.169 * * * \\
(0.048)\end{array}$ & $\begin{array}{l}0.131 * * * \\
(.031)\end{array}$ & $\begin{array}{c}-2.019 * * * \\
(0.319)\end{array}$ \\
\hline Italy & $\begin{array}{l}0.150 * * * \\
(0.014)\end{array}$ & $\begin{array}{c}-0.099 * * \\
(0.042)\end{array}$ & $\begin{array}{c}-0.337 * * * \\
(0.128)\end{array}$ & $\begin{array}{c}-16.193 * * * \\
(1.604)\end{array}$ \\
\hline Portugal & $\begin{array}{l}0.142 * * * \\
(0.012)\end{array}$ & $\begin{array}{r}-0.019 \\
(0.116)\end{array}$ & $\begin{array}{c}-0.497 * * * \\
(0.138)\end{array}$ & $\begin{array}{c}-7.460 \text { *** } \\
(0.927)\end{array}$ \\
\hline Spain & $\begin{array}{l}0.072^{* * * *} \\
(0.009)\end{array}$ & $\begin{array}{c}0.003 \\
(0.079)\end{array}$ & $\begin{array}{l}0.101 * * * \\
(0.043)\end{array}$ & $\begin{array}{c}-3.023^{* * *} \\
(0.467)\end{array}$ \\
\hline Denmark & $\begin{array}{l}0.005^{* *} \\
(0.002)\end{array}$ & $\begin{array}{c}-0.038^{* * * *} \\
(0.008)\end{array}$ & $\begin{array}{c}-0.018^{* * *} \\
(0.007)\end{array}$ & $\begin{array}{r}-0.064 \\
(0.104)\end{array}$ \\
\hline Norway & $\begin{array}{c}-0.026^{* * *} \\
(0.006)\end{array}$ & $\begin{array}{r}-0.019 \\
(0.019)\end{array}$ & $\begin{array}{l}0.050 * * * \\
(0.018)\end{array}$ & $\begin{array}{l}2.374 * * * \\
(0.248)\end{array}$ \\
\hline Sweden & $\begin{array}{l}0.032 * * * \\
(0.003)\end{array}$ & $\begin{array}{c}0.008 \\
(0.006)\end{array}$ & $\begin{array}{l}0.096^{* * *} \\
(0.013)\end{array}$ & $\begin{array}{c}-1.136^{* * *} \\
(0.141)\end{array}$ \\
\hline United Kingdom & $\begin{array}{r}-0.004 \\
(0.003)\end{array}$ & $\begin{array}{l}0.055^{* * *} \\
(0.016)\end{array}$ & $\begin{array}{l}.073 * * * \\
(0.019)\end{array}$ & $\begin{array}{l}0.501 * * * \\
(0.132)\end{array}$ \\
\hline Czech Republic & $\begin{array}{r}-0.007 \\
(0.014)\end{array}$ & $\begin{array}{c}-0.136 * * * \\
(0.028)\end{array}$ & $\begin{array}{c}-0.046 \\
(0.051)\end{array}$ & $\begin{array}{l}1.472 * * * \\
(0.572)\end{array}$ \\
\hline Hungary & $\begin{array}{c}0.058^{* *} \\
(0.023)\end{array}$ & $\begin{array}{c}-0.127 * * * \\
(0.055)\end{array}$ & $\begin{array}{c}-0.056 \\
(0.063)\end{array}$ & $\begin{array}{c}0.314 \\
(1.648)\end{array}$ \\
\hline Poland & $\begin{array}{c}-0.028 \\
(0.029)\end{array}$ & $\begin{array}{c}-0.278 * * * \\
(0.080)\end{array}$ & $\begin{array}{c}0.118 \\
(0.145)\end{array}$ & $\begin{array}{l}4.773 * * * \\
(1.358)\end{array}$ \\
\hline
\end{tabular}

Robust standard errors in parentheses

*, **, *** Significance at the level of 10,5 and $1 \%$, respectively

sign. Finally, note the sizeable differences in the constant terms which raise some doubts on the specification given that the yields of the eurozone countries did not differ much until 2010. 
Table 3 Test of parameter constancy

\begin{tabular}{llllll}
\hline & $\begin{array}{l}\text { All } \\
\text { countries }\end{array}$ & $\begin{array}{l}\text { Eurozone } \\
\text { countries }\end{array}$ & $\begin{array}{l}\text { Non-eurozone } \\
\text { countries }\end{array}$ & $\begin{array}{l}\text { Eurozone crisis } \\
\text { countries }\end{array}$ & $\begin{array}{l}\text { Eurozone non-crisis } \\
\text { countries }\end{array}$ \\
\hline$\chi^{2}$ & 2866 & 1137 & 1510 & 489.4 & 162.9 \\
Prob $>\chi^{2}$ & 0.000 & 0.000 & 0.000 & 0.000 & 0.000 \\
\hline
\end{tabular}

$H_{0}$ Parameter constancy

To test for poolability of the heterogenous countries in one panel regression we run a random coefficient panel estimation that uses the same first stage regression and tests for poolability. The test is algebraically identical to a test of equality of the country specific coefficients (Johnston and DiNardo 1997). We present the test results for the whole sample and the four sub-group panel regression in Table 3.

Besides treating heterogeneous countries adequately, an attractive feature of the mean group estimator is that it's common correlated effects version can handle nonstationary variables. Non-stationarity found in the time-series of the spreads and the debt-to-GDP ratios is therefore well treated. We nevertheless report Augmented Dickey-Fuller and Kwiatkowski-Phillips-Schmidt-Shin tests in "Appendix 2" (Tables 9 and 10). Applying this estimator reduces the significance of the coefficients considerably. Results for whole sample and the subsample of eurozone countries are given in Table 11 in "Appendix 2".

The bottom line from the mean group estimator-approach is that the evidence drawn from regression analysis using quarterly data is the relationship between "fundamentals" and interest spreads is country-specific. One way to proceed would be the route taken by Gibson et al. (2012) and look at cointegration relationships and VEC models. The great advantage of this approach is the 'natural' benchmark it provides in assessing the spreads. We nevertheless decided against using time-series techniques because the pattern in the crisis might not be well explained by slowmoving long-run determinants. From an empirical perspective it is questionable whether using quarterly and in some cases monthly data is appropriate in explaining the movements of interest rates or their spreads during the crisis. A graph of the bond yields as given in Fig. 2 for Greece is instructive. Up to early 2010, the yields have barely changed. After 2010, however, they have changed drastically at certain dates. This indicates why lower frequency data might be not optimal for explaining the changes in yield spreads. Also, visual inspection suggests that movements in spreads are related to specific news events such as the announcement of a fiscal assistance package in May 2010. In the next section, we use event study techniques on high frequency (daily) data to support this hypothesis more rigorously.

\section{Evidence from an event study with daily data}

The econometric analysis of the previous section reveals that it is hard to establish a common pattern in the determinants of yield spreads in the eurozone. On the other hand, so far there is no reason to claim that sentiments which are unrelated to 


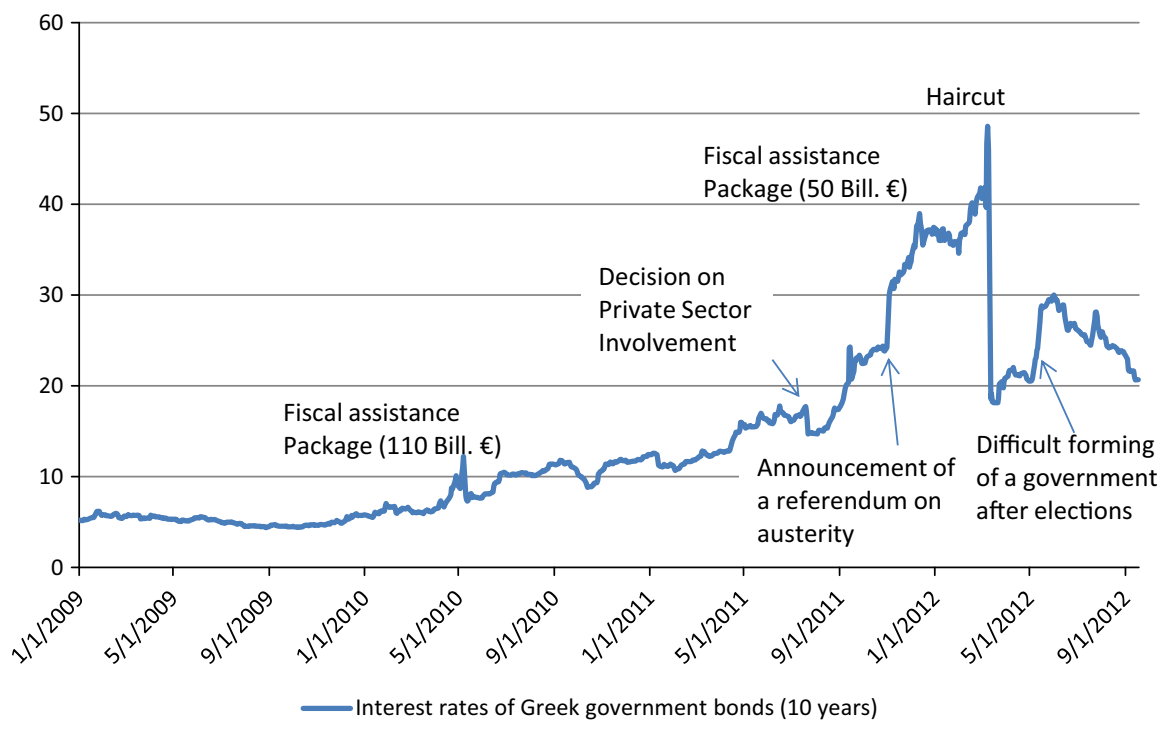

Fig. 2 Greek government bond interest rates, 2009-2013

fundamentals are driving these risk premia. To study the determinants of the yield spread further, we use higher frequency data of government bond yields in the crisis countries.

The data on government bond yields in this section are taken from the ThomsonReuters Datastream and consist of daily observations of the effective annual yield of government bonds with a residual maturity of 10 years. For the event study exercise we restrict the analysis to the five "crisis countries", Greece, Ireland, Italy, Portugal, and Spain. The critical task in our event study is the identification and selection of events. We differentiate between three categories of events: "economic forecasts", "fiscal assistance" and "austerity measures". We focus on these events, because they are most closely connected to news about the fundamental solvency of governments. The information on events comes from two officially assembled, publicly available time-lines, one from the European Commission (EC) ${ }^{5}$ and another one from the European Central Bank $^{6}$ which list all the policy decisions taken by the eurozone governments and provide the press releases associated with these decisions.

A particular problem in event studies is to define the time period over which the impact of an event is measured. For instance, in event studies investigating the impact of earnings announcements on a firm's value, it is common to define an event time window including the day of the announcement as well as the day immediately before and the day immediately after the announcement. Here we extend our event window to 4 days before and 4 days after the event day to hedge

\footnotetext{
5 http://ec.europa.eu/economy_finance/crisis/index_en.htm.

${ }^{6}$ https://www.ecb.europa.eu/ecb/html/crisis.de.html.
} 
against the possibility of assigning the wrong date to an event. As a robustness check, we also performed the event study with longer time windows (up to 10 days) and found that our results are not significantly affected by this choice. ${ }^{7}$

In order to study the impact of an event on the bond yield, it is necessary to create a benchmark that resembles the performance of a bond in absence of the event under investigation. In stock market event studies one typically resorts to a market portfolio of stocks similar to the stock under investigation (MacKinley 1997). The bond market analogue of a market portfolio would be a euro area average of bond yields, or even a world-wide average. However this approach is problematic because the correlation between the average eurozone bond yield and yields of crisis countries is very weak.

Theory suggests that the yield of any bond should be equal to the risk-free interest rate plus a risk premium reflecting investor's expectations of the future solvency of the bond issuer. Assuming that risk aversion does not vary (very much) with time, the yield should remain the same as long as there is no event that changes investor's expectations. We provide two different benchmarks that are based on that proposition. Our first benchmark (BM1) is the yield of day before the event window starts. This means, we implicitly assume that the bond yields follow a simple random walk. If we denote the country $i$ 's government bond yield observed at day $t$ with $R_{i, t}$, the assumption can be formalized as follows: $R_{i, t}=R_{i, s-1}+\epsilon_{i, t}$, where $R_{s}=R_{t-10}$ is the first day of the event window and $\epsilon_{i t}$ is a zero-mean error term. The second benchmark (BM2) is a moving average of the last 20 observations of yields before the event window starts.

The benchmarks are used to calculate the abnormal returns associated with a given event. For our first two benchmarks the abnormal return on day $t$ is the difference between the actual yield on that day and the benchmark yield, i.e. $A R_{i, t}=$ $R_{i, t}-R_{i, s-1}$ in the case of benchmark 1 and $A R_{i, t}=R_{i, t}-\frac{1}{20} \sum_{v=s-21}^{s-1} R_{i, v}$ in the case of benchmark 2. In addition, we calculate one more measure of abnormal returns (BM3), which is based on the assumption that the bond yields follow a first-order autoregressive process

$$
R_{i, v}=\alpha_{i}+\beta_{i} R_{i, s-1}+\epsilon_{i, v},
$$

We run this regression for each country in our sample excluding those days which belong to an event time window. The abnormal return $(A R)$ on day $t$ is then simply calculated as the difference between the actual yield and the predicted yield:

$$
A R_{i, t}=R_{i, t}-\hat{\alpha_{i}}-\hat{\beta_{i}} R_{i, s-1}
$$

where $\hat{\alpha_{i}}, \hat{\beta_{i}}$ denote the estimated parameters of the AR (1) process.

Using the abnormal returns, one can draw inferences on the impact of a given event on the bond yield. Our main interest in this event study is to see which categories of events have an impact on the behavior of government bond yields. For that purpose we calculate the cumulated abnormal return associated with events. For an event occurring on day $t$, the cumulated abnormal return is

\footnotetext{
7 In the text, we only report the results based on the 9-day windows. Results for other time windows are available from the authors on request.
} 


$$
C A R_{i, t}=\sum_{s=t-4}^{t+4} A R_{i, s} .
$$

We want to test wether any particular category of event has a positive or negative impact on a country's government bond yield. In order to test that, we perform a sign test. Under the null hypothesis that an event category (e.g., "economic forecast") has no impact on the yield, the expected value of the cumulated abnormal returns associated with the events in that category is zero. Assuming further that the $C A R$ s are symmetrically distributed, it is equally probable that the $C A R$ associated with any event in the category is positive or negative.

Now let $N$ be the total number of events in a given event category and let $N^{+}$be the number of events for which the cumulated abnormal return is positive. Then the sign test is given by

$$
\theta=\left[\frac{N^{+}}{N}-0.5\right] \frac{\sqrt{N}}{0.5} .
$$

Under our assumptions, $\theta$ follows asymptotically a standard normal distribution (MacKinley 1997). Hence, the calculated $\theta$ s can be compared to the critical values of the standard normal distribution.

\subsection{Economic forecast events}

The EC publishes twice a year forecasts of key economic indicators for all EU member countries, including forecasts of GDP growth and budget deficits. Until 2011, the EC also published interim forecasts between the semiannual forecast releases. These forecasts are important to investors for assessing the future solvency of governments. We want to test whether the forecast publications have a significant impact on government bond yields.

Of the 16 forecasts released in the period between 2009 and 2013, we include nine forecasts in the event study. The criterion for inclusion is that each of these forecasts predicted a deterioration either in real GDP growth, in the debt-to-GDP ratio or in the budget deficit compared to the previous forecast release. ${ }^{8}$ This is a conservative criterion for "bad news", because it causes us to leave out all forecast releases that, although predicting bad economic fundamentals by historical standards (e.g., higher debt-to-GDP ratios or lower real GDP growth compared to historical averages), did not constitute a deterioration compared to the precious forecast. In this (strong) sense all the selected forecasts can be considered "bad news" for investors, so that they can be expected to increase the interest rate of government bonds. In principle, we would like to test the hypothesis that bond yields react to positive forecasts. However, there simply aren't enough positive forecasts in the period of observation.

Figure 3 shows the mean of the cumulated abnormal returns associated with the release of negative economic forecasts 4 days before and 4 days after the day of the

\footnotetext{
${ }^{8}$ A list of event dates is available from the authors on request.
} 


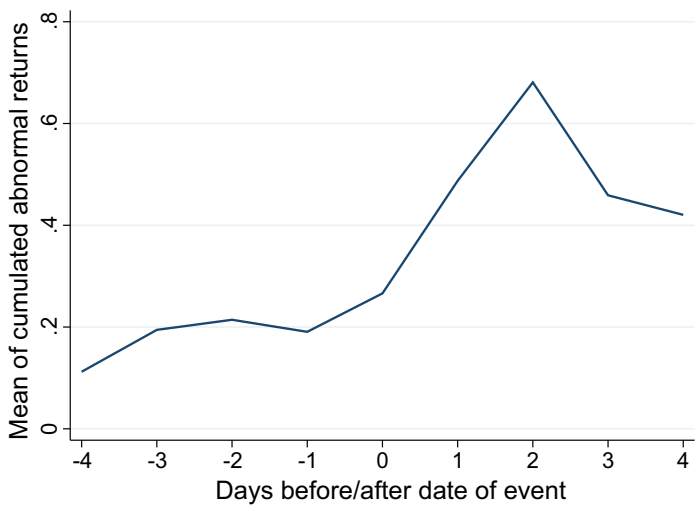

Fig. 3 Cumulated abnormal returns, economic forecast events

Table 4 Sign test for economic forecast events

\begin{tabular}{lllll}
\hline & $N$ & $N^{+}$ & $\theta$ & $p$ value \\
\hline BM1 & 45 & 36 & $4.025^{* * * *}$ & 0.000 \\
BM2 & 45 & 29 & $1.938^{*}$ & 0.053 \\
BM3 & 45 & 33 & $3.130^{* * *}$ & 0.002 \\
\hline
\end{tabular}

$*$, **, *** Significance at the level of 10,5 , and $1 \%$, respectively

release. The graph shows that, on average, bond yields rose by over 0.4 percentage points during the time around the forecast release. Table 4 gives the results of the sign test for economic forecasts, using the three different benchmarks described above. For all benchmarks, the sign test is positive and distinct from zero at conventional significance levels. This can be read as evidence that the government bond yields indeed react to negative economic forecasts.

\subsection{Fiscal assistance events}

The most severely hit eurozone countries received fiscal assistance from other eurozone governments as well as from the IMF. The first country to ask for help was Greece in May 2010, followed by Ireland in November 2010 and Portugal in May 2011. Assistance funds were only paid out after the "troika", consisting of the European Commission, ECB and IMF, had assessed the reform programs on which the assistance was conditioned. The announcements of new disbursements of assistance funds can therefore be seen as "good news" to the bond market and should be associated with a reduction in the borrowing costs of the receiving governments.

Looking at Fig. 4, shows that the mean of cumulated abnormal returns around fiscal assistance events is small and seems to increase slightly, instead of decrease as one would expect, during an 8-day period surrounding the day of events. As shown in Table 5, the fiscal assistance events do not seem to have a significant impact on the government's borrowing costs. The sign test fails to reject the null of no reaction 


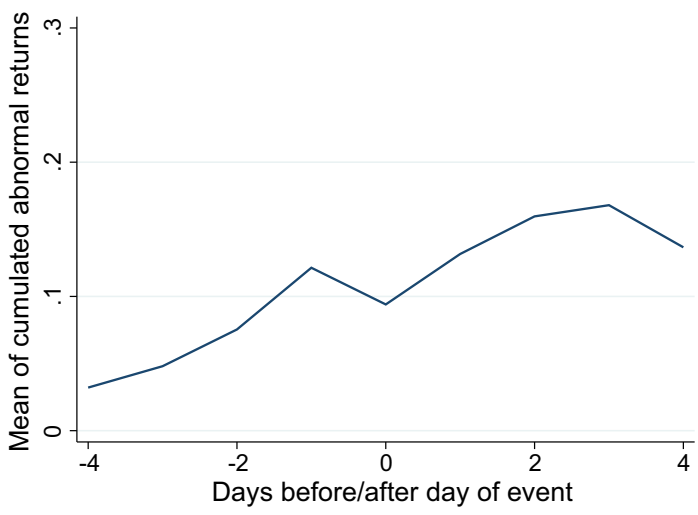

Fig. 4 Cumulated abnormal returns, fiscal assistance news

Table 5 Sign test for fiscal assistance events

\begin{tabular}{lllll}
\hline & $N$ & $N^{+}$ & $\theta$ & $p$ value \\
\hline BM1 & 14 & 8 & 0.535 & 0.593 \\
BM2 & 14 & 8 & 0.535 & 0.593 \\
BM3 & 14 & 8 & 0.535 & 0.593 \\
\hline
\end{tabular}

to fiscal assistance for all three benchmarks. ${ }^{9}$ This could suggest either that investors do not believe that the assistance packages improve the future solvency of the targeted government sufficiently, or that the market has already priced in the effect of those packages at an earlier date. However, one should be careful to draw general conclusions from these results, since the number of events in this category is rather small.

\subsection{Austerity measures}

As already mentioned above, the fiscal assistance from eurozone governments and the IMF was conditioned on fiscal and structural reforms on the part of the receiving governments. These reforms aimed at cutting the public deficit by reducing (current and future) government spending and increasing taxes. Hence one would expect to improve the long-run solvency prospect and thus to bring down the borrowing costs of the affected governments. Therefore, we selected 36 announcements of "austerity measures" such as plans to increase taxes, cut spending or to implement structural reforms. Most of these announcements affected Greece, Ireland and Portugal. Again, information on these events are taken from the EC time-line mentioned above.

\footnotetext{
9 Given the small sample size of 14 observed events, the sign test should be interpreted with care. Alternatively, under the null of no reaction to fiscal assistance news, the probability of observing at least 8 positive CARs out of 14 is 0.212 assuming they are statistically independent. This is evidence for the null.
} 
Table 6 Sign test for austerity

\begin{tabular}{lllll}
\hline & $N$ & $N^{+}$ & $\theta$ & $p$ value \\
\hline BM1 & 36 & 21 & 1.000 & 0.317 \\
BM2 & 36 & 20 & 0.667 & 0.505 \\
BM3 & 36 & 22 & 1.333 & 0.182 \\
\hline
\end{tabular}

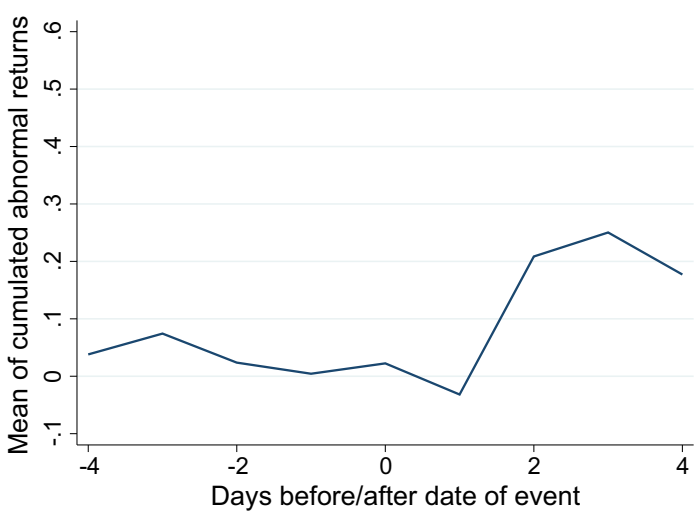

Fig. 5 Cumulated abnormal returns, austerity news

In Table 6 we again report the sign tests of these "austerity events". For all three benchmarks, we do not find a significant effect of the austerity measures. Taken together with the results from the fiscal assistance packages, one can conclude that the "bailout-cum-austerity" approach failed to have a measurable effect on the government borrowing costs. This result is supported by Fig. 5 which shows a very small reaction of the interest rates during the event time-window. As in the case of fiscal assistance events, the reaction seems to be in the wrong direction, going up after the announcement of austerity policies rather than down. This indicates that the markets did not react to announcements of austerity policies.

However, this result should be interpreted with care. It is conceivable that investors anticipated some of the austerity measures before their official announcement. If the announced policies were "less austere" than expected, we would expect the bond yields to rise instead of fall during the event time-window. If this was the case, our findings could alternatively be interpreted to show that austerity policies were "not as austere", on average, as previously expected by the market.

\section{Event-dummy regressions}

The event study demonstrates that news events have a statistically significant and predictable effect on the interest rates of crisis-countries' government bonds. However, in the sign tests we could use only those events that occur in sufficiently 
large number which requires that they occur in all crisis countries. Yet, we have argued above that the sources and triggers of the crises have been quite different between countries. We therefore present in this section an approach that allows us to include singular country-specific events.

We start with the Greek example that is visualized in Fig. 2. We explain the change in the Greek interest rate only by the events used in the event study above and a set of additional Greece-specific events. As in the previous section, all events are taken from the publicly available time-lines mentioned above. The Greecespecific events included in these regressions fall in three categories: national policy actions or policy-related developments (such as public protests against austerity measures), extra-ordinary interventions by the ECB in the government bond markets such as the Securities Market Program (SMP), the Long-Term Refinancing Operations (LTRO), and the Outright Monetary Transactions (OMT), and changes in credit ratings by rating agencies. Our hypothesis is that all these events contained (good or bad) news for bond investors and hence should be associated with significant changes in the interest rate.

Using the first difference of the interest rate solves two problems: (1) it gives us a stationary series which allows us to use simple OLS regressions and (2) it eliminates those fundamental determinants of interest rates which do not change from 1 day to another for reasons unrelated to the events. Employing a regression approach also allows us to assess the economic importance of an event by looking at the size of the estimated coefficients. The coefficient of the event dummy gives the average effect of the event on the daily interest rate change in percentage points. Moreover, it is instructive to analyze how much of the variation in the data is explained by any given set of events.

By far the most important event dwarfing everything else is the debt rescheduling in March 2012, also known as "haircut", which brought down the Greek interest rate by 27 percentage points (see column (2) in Table 7). This single-day event explains $76 \%$ of the variation in the bond yield. Large increases in the Greek interest rate were associated with the political uncertainty dummy as well as with the 2011 referendum on austerity measures. The extraordinary policy measures by the ECB (the SMP, LTRO and OMT programs) significantly reduced the interest rate for Greece, although the effects seem to be rather small. It should be kept in mind, however, that our regressions only capture short-run effects and cannot assess any long-run effects these measures might have had.

In columns (4) and (5) in Table 7 we included a dummy for credit downgrading events. Credit rating agencies base their rating decisions on country-specific news and some analysis of the fundamentals. In so far as the credit rating agencies have some information about fundamentals that the general public doesn't have, there should be a significant (positive) effect of downgrading events. We focused on Moody's credit ratings to construct the downgrading dummies since they can be taken to be representative of the ratings of other agencies. ${ }^{10}$ The estimated coefficient in column (4) is negative, indicating a decline in the Greek interest rate

\footnotetext{
${ }^{10}$ Downgrading decisions were highly synchronized across rating agencies so that the choice of agency doesn't affect the results.
} 
Table 7 Event-dummy regressions: Greece, 1/1/2007-9/3/2013

\begin{tabular}{|c|c|c|c|c|c|}
\hline & $\begin{array}{l}\text { (1) } \\
\text { Common events }\end{array}$ & $\begin{array}{l}\text { (2) } \\
\text { Haircut }\end{array}$ & $\begin{array}{l}\text { (3) } \\
\text { All, without ratings }\end{array}$ & $\begin{array}{l}\text { (4) } \\
\text { Ratings only }\end{array}$ & $\begin{array}{l}(5) \\
\text { All }\end{array}$ \\
\hline Assistance & $\begin{array}{l}-0.01 \\
(0.120)\end{array}$ & & $\begin{array}{l}- \\
(0.062)\end{array}$ & & $\begin{array}{l}0.164 * * \\
(0.062)\end{array}$ \\
\hline Austerity & $\begin{array}{l}-0.17 * * * \\
(0.065)\end{array}$ & & $\begin{array}{l}0.0236 \\
(0.029)\end{array}$ & & $\begin{array}{l}0.001 \\
(0.031)\end{array}$ \\
\hline Forecast & $\begin{array}{l}- \\
(0.062)\end{array}$ & & $\begin{array}{l}0.021 \\
(0.029)\end{array}$ & & $\begin{array}{l}0.014 \\
(0.0344)\end{array}$ \\
\hline Haircut & & $\begin{array}{l}-27.49^{* * *} \\
(0.369)\end{array}$ & $\begin{array}{l}-27.508^{* * *} \\
(0.345)\end{array}$ & & $\begin{array}{l}-27.559 * * * \\
(0.345)\end{array}$ \\
\hline EDP & & & $\begin{array}{l}0.111 \\
(0.343)\end{array}$ & & $\begin{array}{l}0.115 \\
(0.343)\end{array}$ \\
\hline Eurostat & & & $\begin{array}{l}0.074 \\
(0.199)\end{array}$ & & $\begin{array}{l}0.077 \\
(0.198)\end{array}$ \\
\hline SMP & & & $\begin{array}{l}-0.529 * * * \\
(0.153)\end{array}$ & & $\begin{array}{l}-1.827 * * * \\
(0.208)\end{array}$ \\
\hline LTRO & & & $\begin{array}{l}-0.529 * * * \\
(0.153)\end{array}$ & & $\begin{array}{l}-0.522 * * * \\
(0.153)\end{array}$ \\
\hline Political uncertainty & & & $\begin{array}{l}0.954 * * * \\
(0.119)\end{array}$ & & $\begin{array}{l}0.966^{* * *} \\
(0.119)\end{array}$ \\
\hline Troika & & & $\begin{array}{l}-0.028 \\
(0.141)\end{array}$ & & $\begin{array}{l}-0.036 \\
(0.140)\end{array}$ \\
\hline Rescheduling & & & $\begin{array}{l}-1.057 * * * \\
(0.344)\end{array}$ & & $\begin{array}{l}-1.131^{* * * *} \\
(0.345)\end{array}$ \\
\hline Referendum & & & $\begin{array}{l}1.897 * * * \\
(0.200)\end{array}$ & & $\begin{array}{l}1.908^{* * *} \\
(0.200)\end{array}$ \\
\hline OMT & & & $\begin{array}{l}-0.470^{* *} \\
(0.199)\end{array}$ & & $\begin{array}{l}-0.467 * * \\
(0.198)\end{array}$ \\
\hline Downgrading & & & & $\begin{array}{l}-0.133^{*} \\
(0.067)\end{array}$ & $\begin{array}{l}0.077 * * \\
(0.033)\end{array}$ \\
\hline Constant & $\begin{array}{l}0.01 \\
(0.019)\end{array}$ & $\begin{array}{l}0.02 * * \\
(0.01)\end{array}$ & $\begin{array}{l}0.009 * \\
(0.009)\end{array}$ & $\begin{array}{l}0.014 \\
(0.019)\end{array}$ & $\begin{array}{l}0.006 \\
(0.009)\end{array}$ \\
\hline Adj. $R^{2}$ & 0.004 & 0.762 & 0.793 & 0.002 & 0.794 \\
\hline Observations & 1741 & 1741 & 1741 & 1741 & 1741 \\
\hline
\end{tabular}

Assistance, Austerity, and Forecast: see previous section for description; Haircut: announcement of private sector involvement on the March 12th 2012 (single day event); EDP: European Commission announcement of Excessive Debt Procedures; Eurostat: Eurostat report on fraudulent statistics from the Greek government; SMP: announcement of Securities Market Program by the ECB on May 9th 2010; LTRO: announcement of Long-Term Refinancing Operations by the ECB on December 8th 2011; Political uncertainty: political protest activity around the introduction of austerity measures and the difficult time forming the government in May 2012; Troika: reports by the troika; Rescheduling: announcement of debt rescheduling on June 21st 2011; Referendum: announcement of a referendum on austerity measures on October 31st 2011; OMT: first announcement of Outright Monetary Transactions program by the ECB on July 26th 2012; Downgrading: downgrading in Greece's country rating. All event windows are set to 9, 4 days before and after the event day, unless otherwise indicated

Robust stand. errors in parentheses

$*$, **, *** Significance at the level of $10,5,1 \%$ 
around downgrading events, which is a paradoxical result. After controlling for other events, the downgrading coefficient has the expected sign but is rather small in size [see column (5)]. Taken together, these results suggest, that the mildly negative effect of downgradings is confounded by other events occurring around the same time. One caveat in interpreting this result is that we only look at downgrading decisions and leave out warnings which are typically issued by the rating agencies in advance. This reduces the marginal news content embodied in downgrading decisions and may bias our estimates downward.

We applied the same approach to three other countries: Ireland, Portugal, and Spain (see Tables 12, 13, 14 in "Appendix 2"). We left out Italy for the event regression exercise, because there were too little Italy-specific events that could have been employed in a meaningful way in these regressions. For Ireland and Spain, the most drastic movements in the interest rate occurred around events involving the domestic banking sector. In the case of Ireland, the nationalization of Anglo Irish Bank in January 2009 led to a first jump in the government interest rate, followed by further increases during autumn 2010, when major Irish banks faced severe refinancing problems and the government stepped in by means of large-scale capital injections. In Spain, the government bailout for Bankia in May 2012 had a similar impact. In contrast to Greece, the official assistance packages from the EU and the IMF seem to have had a significant (negative) impact on Irish borrowing costs. In Portugal and Spain, we find some significant positive effect of downgrading events.

We also find that the extraordinary policy measures pursued by the ECB had a sizable dampening impact on government borrowing costs, although the size of the effect varies across countries. For instance, the announcement of the SMP reduced the Spanish interest rate by about 0.2 percentage point per day, whereas the effect on the Irish interest rate was -0.4 percentage points per day. The effect of the LTRO announcement seems to be less clear. The first announcement of the OMT did have a negative impact on Greek and Spanish interests rate, while the effect on Irish and Portuguese yields is (statistically) insignificant.

The evidence on the effect of the extraordinary actions by the ECB could be interpreted in two ways. On the one hand, these programs helped to improve the solvency of troubled governments by reducing their interest payment burden directly or indirectly by supporting the national banking systems which, in turn, reduced the likelihood of costly government bailouts in the future. In this sense, the announcement of the extraordinary ECB actions constituted "good news" on the fundamental determinants of debt sustainability. On the other hand, these announcements can also be understood as signals on the part of the ECB to prevent self-fulfilling bad equilibria in the government bond markets. Indeed, these programs have sometimes been defended precisely on this theory. On this second interpretation, our findings suggest that the interest spreads in the eurozone were at least party driven by self-fulfilling sentiments. 


\section{Summary and conclusion}

The recent debate on interest rates on government bonds has very much concentrated on irrationality, sentiments, and multiple equilibria. Most of the evidence presented by the existing literature is based on panel regressions using low frequency data. We find these regressions problematic for three reasons: first, it is often unclear which explanatory variables to include in the regression and what functional form should be used. Second, we showed in this paper that the poolability assumption underlying the panel approach is not met in the present case of European countries. Third, the results obtained from these regressions could be spurious due to the non-stationarity of both the dependent and independent variables.

We therefore turn our attention to daily data and analyze the impact of singular news events on the interest rates of government bonds. The event study shows consistently that bad news on fiscal fundamentals such as debt-to-GDP ratios, budget deficits and real growth prospects are associated with increasing government bond yields. What is more important for the political debate, however, is that we find no measurable reaction of interest rates to the announcement of austerity measures or fiscal assistance packages. Hence, while our results indicate that government interest rates in the eurozone do indeed respond to economic forecasting news, we do not find evidence that there was a measurable reaction to the political actions taken by the European governments. In contrast, the event dummy regressions reveal a significant effect of the extraordinary interventions by the ECB (e.g., the securities market program) on interest rates, particularly for Ireland, Spain, and Portugal.

The difficulty to find significant effects of policy actions when pooling over countries stems from the heterogeneity of the crisis countries. As becomes clear in the event dummy regressions, each country is different with regard to the underlying causes as well as the chronological development of the crisis. It seems that the only characteristic all crisis countries have in common is their membership in the eurozone. Methodologically, there is therefore no good reason to group those countries together at any level of aggregation in order to look for common determinants of government interest rates. Politically, it seems important to take the differences in the sources of the crisis into account by designing country-specific policy actions to overcome the crisis.

Acknowledgments Open access funding provided by University of Graz.

Open Access This article is distributed under the terms of the Creative Commons Attribution 4.0 International License (http://creativecommons.org/licenses/by/4.0/), which permits unrestricted use, distribution, and reproduction in any medium, provided you give appropriate credit to the original author(s) and the source, provide a link to the Creative Commons license, and indicate if changes were made.

\section{Appendix 1: Data sources}

See Table 8. 
Table 8 Data description and sources

\begin{tabular}{|c|c|c|c|}
\hline $\begin{array}{l}\text { Variable } \\
\text { name }\end{array}$ & Description & Source & Sample \\
\hline Spread & $\begin{array}{l}\text { Spread in the interest rate on long-term } \\
\text { (in most cases } 10 \text { year) government } \\
\text { bonds over the German benchmark } \\
\text { bond }\end{array}$ & $\begin{array}{l}\text { Long-term interest rates, Monthly } \\
\text { Monetary and Financial } \\
\text { Statistics (MEI), OECD }\end{array}$ & $\begin{array}{l}\text { 1st quarter } \\
2001-1 \text { st } \\
\text { quarter } \\
2013\end{array}$ \\
\hline Debt & $\begin{array}{l}\text { Ratio of gross government debt to gross } \\
\text { domestic product }\end{array}$ & $\begin{array}{l}\text { Quarterly government debt } \\
\text { (general government), Quarterly } \\
\text { government debt statistics (gov- } \\
\text { 10q), Eurostat }\end{array}$ & $\begin{array}{l}\text { 1st quarter } \\
2001-1 \text { st } \\
\text { quarter } \\
2013\end{array}$ \\
\hline Growth & $\begin{array}{l}\text { Annualized growth rate of gross } \\
\text { domestic product at constant prices, } \\
\text { Chain-linked volumes }(2010)\end{array}$ & $\begin{array}{l}\text { GDP and main components, } \\
\text { Quarterly national accounts } \\
\text { (namq-10), Eurostat }\end{array}$ & $\begin{array}{l}\text { 1st quarter } \\
2001-1 \text { st } \\
\text { quarter } \\
2013\end{array}$ \\
\hline Deficit & $\begin{array}{l}\text { Ratio of primary budget deficit, defined } \\
\text { as difference between total non- } \\
\text { interest spending and total revenue of } \\
\text { general government, to gross } \\
\text { domestic product }\end{array}$ & $\begin{array}{l}\text { Quarterly non-financial accounts } \\
\text { for general government, } \\
\text { Quarterly government debt } \\
\text { statistics (gov-10q), Eurostat }\end{array}$ & $\begin{array}{l}\text { 1st quarter } \\
2001-1 \text { st } \\
\text { quarter } \\
2013\end{array}$ \\
\hline$R$ & $\begin{array}{l}\text { Interest rate on long-term (10 years) } \\
\text { government bonds }\end{array}$ & $\begin{array}{l}\text { BDBRYLD, PTBRYLD, } \\
\text { ESBRYLD, ITBRYLD } \\
\text { IRBRYLD, GRBRYLD, } \\
\text { PTBRYLD, Thompson-Reuters } \\
\text { Datastream }\end{array}$ & $\begin{array}{l}1 / 1 / 2007-9 / \\
3 / 2013\end{array}$ \\
\hline
\end{tabular}

\section{Appendix 2: Regression tables and tests not included in main text}

See Tables 9, 10, 11, 12, 13 and 14.

Table 9 Unit root and stationarity tests, debt-to-GDP ratios

\begin{tabular}{llll}
\hline & ADF unit root test & & KPSS test for stationarity \\
\cline { 2 - 4 } & Test & $\begin{array}{l}\text { MacKinnon } \\
p \text { value }\end{array}$ & $\begin{array}{l}\text { Test } \\
\text { Statistic }\end{array}$ \\
\hline Austria & Statistic & 0.000 & $0.175^{* *}$ \\
Belgium & $-5.023^{* * *}$ & 0.998 & $0.252^{* * *}$ \\
Czech Republic & 1.642 & 0.001 & $0.141^{*}$ \\
Denmark & $-4.186^{* * *}$ & 0.000 & $0.241^{* * *}$ \\
Finland & $-4.776^{* * *}$ & 0.840 & $0.251^{* * *}$ \\
France & -0.726 & 0.000 & $0.227^{* * *}$ \\
Greece & $-25.542^{* * *}$ & 0.869 & $0.243^{* * *}$ \\
Hungary & -0.611 & 0.000 & $0.141^{*}$ \\
Ireland & $-4.829^{* * *}$ & 0.000 & $0.276^{* * *}$ \\
Italy & $17.324^{* * *}$ & 0.334 & $0.241^{* * *}$ \\
Netherlands & -1.897 & 0.000 & $0.214^{* *}$ \\
Norway & $-10.633^{* * *}$ & 0.000 & $0.226^{* * *}$ \\
\hline
\end{tabular}


Table 9 continued

\begin{tabular}{|c|c|c|c|}
\hline & \multicolumn{2}{|c|}{$\mathrm{ADF}$ unit root test } & \multirow{2}{*}{$\begin{array}{l}\text { KPSS test for stationarity } \\
\text { Test } \\
\text { Statistic }\end{array}$} \\
\hline & $\begin{array}{l}\text { Test } \\
\text { Statistic }\end{array}$ & $\begin{array}{l}\text { MacKinnon } \\
p \text { value }\end{array}$ & \\
\hline Poland & $-11.920 * * *$ & 0.000 & $0.139 * *$ \\
\hline Portugal & -2.401 & 0.141 & $0.242 * * *$ \\
\hline Spain & 2.763 & 1.000 & $0.278 * * *$ \\
\hline Sweden & $-2.625^{*}$ & 0.088 & 0.062 \\
\hline United Kingdom & 0.561 & 0.987 & $0.253 * *$ \\
\hline
\end{tabular}

ADF-H0: Debt-GDP ratio relative to Germany contains unit root. Interpolated Dickey-Fuller critical values: $-2.607(10 \%),-2.947(5 \%),-3.621(10 \%)$. The maximum lag length is set to 4. KPSS-H0: Debt-GDP ratio relative to Germany is trend-stationary. Critical values: $10 \% 0.119,5 \% 0.146,1 \%$ 0.216 . The maximum lag length is set to 4

$*$, **, *** Significance at the level of 10,5 , and $1 \%$, respectively

Table 10 Unit root and stationarity tests, interest rate spreads

\begin{tabular}{|c|c|c|c|}
\hline & \multicolumn{2}{|c|}{ ADF unit root test } & \multirow{2}{*}{$\begin{array}{l}\text { KPSS stationarity test } \\
\text { Test } \\
\text { Statistic }\end{array}$} \\
\hline & $\begin{array}{l}\text { Test } \\
\text { Statistic }\end{array}$ & $\begin{array}{l}\text { MacKinnon } \\
p \text { value }\end{array}$ & \\
\hline Austria & $-6.043^{* * *}$ & 0.000 & $0.167 * *$ \\
\hline Belgium & $-3.121 * *$ & 0.025 & $0.191 * *$ \\
\hline Czech Republic & $-3.367 * * *$ & 0.012 & $0.138 *$ \\
\hline Denmark & $-18.054 * * *$ & 0.000 & 0.097 \\
\hline Finland & $-10.627^{* * * *}$ & 0.000 & $0.141 *$ \\
\hline France & $-5.478 * * *$ & 0.000 & $0.204 * *$ \\
\hline Greece & 0.420 & 0.982 & $0.213^{* *}$ \\
\hline Hungary & $-3.319 * *$ & 0.014 & 0.073 \\
\hline Ireland & 1.166 & 0.996 & $0.175^{* *}$ \\
\hline Italy & $-2.754^{*}$ & 0.065 & $0.220 * * *$ \\
\hline Netherlands & $-8.933 * * *$ & 0.000 & $0.144^{*}$ \\
\hline Norway & $-8.417 * * *$ & 0.000 & $0.196 * *$ \\
\hline Poland & -2.497 & 0.116 & $0.200 * *$ \\
\hline Portugal & -0.303 & 0.925 & $0.199 * *$ \\
\hline Spain & 1.446 & 0.997 & $0.247 * * *$ \\
\hline Sweden & $-10.812 * * *$ & 0.000 & $0.176^{* *}$ \\
\hline United Kingdom & -2.485 & 0.119 & $0.192 * *$ \\
\hline
\end{tabular}

ADF-H0: Spread relative to Germany contains unit root. Interpolated Dickey-Fuller critical values:-2.607 $(10 \%),-2.947(5 \%),-3.621(10 \%)$. The maximum lag length is set to 4. KPSS-H0: Spread relative to Germany is trend-stationary. Critical values: $10 \% 0.119,5 \% 0.146,1 \% 0.216$. The maximum lag length is set to 4

$*, * *, * * *$ Significance at the level of 10,5 , and $1 \%$, respectively 
Table 11 Alternative specifications taking variable non-stationarity into account

\begin{tabular}{|c|c|c|c|c|}
\hline & \multicolumn{2}{|c|}{ MG model including a time tend } & \multicolumn{2}{|c|}{ Common correlated effects MG estimator } \\
\hline & All countries & EMU-countries only & All countries & EMU-countries only \\
\hline \multirow[t]{2}{*}{ Debt } & 0.019 & $0.054 * * *$ & -0.005 & -0.007 \\
\hline & $(0.013)$ & $(0.017)$ & $(0.008)$ & $(0.006)$ \\
\hline \multirow[t]{2}{*}{ Growth } & $-0.037 * * *$ & $-0.039 * * *$ & -0.026 & -0.011 \\
\hline & $(0.014)$ & $(0.010)$ & $(0.025)$ & $(0.013)$ \\
\hline \multirow[t]{2}{*}{ Deficit } & 0.014 & -0.088 & 0.027 & -0.010 \\
\hline & $(0.024)$ & $(0.067)$ & $(0.042)$ & $(0.045)$ \\
\hline \multirow[t]{2}{*}{ Trend } & $0.012 *$ & 0.019 & & \\
\hline & $(0.007)$ & $(0.013)$ & & \\
\hline \multirow[t]{2}{*}{ av. Spread } & & & $0.452 * * *$ & $0.393 * * *$ \\
\hline & & & $(0.147)$ & $(0.131)$ \\
\hline \multirow[t]{2}{*}{ av. Debt } & & & $0.019 * *$ & -0.007 \\
\hline & & & $(0.020)$ & $(0.007)$ \\
\hline \multirow[t]{2}{*}{ av. Growth } & & & -0.006 & $-0.036 * * *$ \\
\hline & & & $(0.026)$ & $(0.011)$ \\
\hline \multirow[t]{2}{*}{ av. Deficit } & & & 0.023 & 0.020 \\
\hline & & & $(0.048)$ & $(0.048)$ \\
\hline \multirow[t]{2}{*}{ Constant } & -0.537 & -4.438 & 0.782 & $0.704 * * *$ \\
\hline & (1.104) & $(1.658)$ & 0.581 & $(0.192)$ \\
\hline Observations & 833 & 490 & 833 & 490 \\
\hline Groups & 17 & 10 & 17 & 10 \\
\hline
\end{tabular}

Robust standard errors in parentheses

$*$, **, *** Significance at the level of 10,5 and $1 \%$, respectively

Table 12 Event-dummy regressions: Ireland, 1/1/2007-9/3/2013

\begin{tabular}{|c|c|c|c|c|}
\hline & $\begin{array}{l}\text { (1) } \\
\text { Common events }\end{array}$ & $\begin{array}{l}\text { (2) } \\
\text { All, without ratings }\end{array}$ & $\begin{array}{l}\text { (3) } \\
\text { Ratings only }\end{array}$ & $\begin{array}{l}(4) \\
\text { All }\end{array}$ \\
\hline Assistance & $\begin{array}{l}-0.027 * * * \\
(0.009)\end{array}$ & $\begin{array}{l}-0.039 * * * \\
(0.009)\end{array}$ & & $\begin{array}{l}-0.038 * * * \\
(0.009)\end{array}$ \\
\hline Austerity & $\begin{array}{l}-0.003 \\
(0.009)\end{array}$ & $\begin{array}{l}-0.013 \\
(0.008)\end{array}$ & & $\begin{array}{l}-0.013 \\
(0.009)\end{array}$ \\
\hline Forecast & $\begin{array}{l}0.013 \\
(0.008)\end{array}$ & $\begin{array}{l}- \\
(0.008)\end{array}$ & & $\begin{array}{l}0.014^{*} \\
(0.008)\end{array}$ \\
\hline EDP & & $\begin{array}{l}-0.124 \\
(0.097)\end{array}$ & & $\begin{array}{l}-0.124 \\
(0.097)\end{array}$ \\
\hline AIB nationalization & & $\begin{array}{l}0.201 * * * \\
(0.043)\end{array}$ & & $\begin{array}{l}0.202 * * * \\
(0.043)\end{array}$ \\
\hline
\end{tabular}


Table 12 continued

\begin{tabular}{|c|c|c|c|c|}
\hline & $\begin{array}{l}\text { (1) } \\
\text { Common events }\end{array}$ & $\begin{array}{l}\text { (2) } \\
\text { All, without ratings }\end{array}$ & $\begin{array}{l}\text { (3) } \\
\text { Ratings only }\end{array}$ & $\begin{array}{l}(4) \\
\text { All }\end{array}$ \\
\hline Banking crisis & & $\begin{array}{l}0.127 * * * \\
(0.022)\end{array}$ & & $\begin{array}{l}0.127 * * * \\
(0.022)\end{array}$ \\
\hline Banks downgrading & & $\begin{array}{l}0.096 * * * \\
(0.031)\end{array}$ & & $\begin{array}{l}0.097 * * * \\
(0.031)\end{array}$ \\
\hline SMP & & $\begin{array}{l}-0.404 * * * \\
(0.056)\end{array}$ & & $\begin{array}{l}-0.403 * * * \\
(0.056)\end{array}$ \\
\hline LTRO & & $\begin{array}{l}-0.004 \\
(0.040)\end{array}$ & & $\begin{array}{l}-0.004 \\
(0.040)\end{array}$ \\
\hline OMT & & $\begin{array}{l}-0.007 \\
(0.056)\end{array}$ & & $\begin{array}{l}-0.006 \\
(0.056)\end{array}$ \\
\hline Downgrading & & & $\begin{array}{l}0.015 \\
(0.011)\end{array}$ & $\begin{array}{l}0.011 \\
(0.012)\end{array}$ \\
\hline Constant & $\begin{array}{l}0.001 \\
(0.002)\end{array}$ & $\begin{array}{l}0.001 \\
(0.003)\end{array}$ & $\begin{array}{l}0.002 \\
(0.003)\end{array}$ & $\begin{array}{l}0.001 \\
(0.003)\end{array}$ \\
\hline Adj. $R^{2}$ & 0.005 & 0.065 & 0.001 & 0.065 \\
\hline Observations & 1741 & 1741 & 1741 & 1741 \\
\hline
\end{tabular}

Assistance, Austerity, Forecast: see previous section for description; EDP: European Commission announcement Excessive Debt Procedures; AIB nationalization: announcement of nationalization of Anglo Irish Bank; Banking crisis: climax of the refinancing problems of major Irish banks in November 2010 (30 days); Banks downgrading: Moody's decision to downgrade Irish bank debt to junk status; SMP: announcement of securities market program by the ECB on May 9th 2010; LTRO: announcement of long-term refinancing operations by the ECB on December 8th 2011; OMT: first announcement of Outright Monetary Transactions program by the ECB on July 26th 2012; Downgrading: change in Ireland's country rating. All event windows are set to 9, 4 days before and after the event day, unless otherwise indicated

Robust standard errors in parentheses

$*$, **, *** Significance at the level of 10,5 and $1 \%$, respectively

Table 13 Event-dummy regressions: Spain, 1/1/2007-9/3/2013

\begin{tabular}{|c|c|c|c|c|}
\hline & $\begin{array}{l}\text { (1) } \\
\text { Common events }\end{array}$ & $\begin{array}{l}\text { (2) } \\
\text { All, without ratings }\end{array}$ & $\begin{array}{l}\text { (3) } \\
\text { Ratings only }\end{array}$ & $\begin{array}{l}(4) \\
\text { All }\end{array}$ \\
\hline Austerity & $\begin{array}{l}0.003 \\
(0.006)\end{array}$ & $\begin{array}{l}0.005 \\
(0.006)\end{array}$ & & $\begin{array}{l}0.004 \\
(0.006)\end{array}$ \\
\hline Forecast & $\begin{array}{l}0.016 * * * \\
(0.006)\end{array}$ & $\begin{array}{l}0.017 * * * \\
(0.006)\end{array}$ & & $\begin{array}{l}0.018 * * * \\
(0.006)\end{array}$ \\
\hline EDP & & $\begin{array}{l}0.090 \\
(0.077)\end{array}$ & & $\begin{array}{l}0.091 \\
(0.077)\end{array}$ \\
\hline Bankia & & $\begin{array}{l}0.038 \\
(0.030)\end{array}$ & & $\begin{array}{l}0.040 \\
(0.030)\end{array}$ \\
\hline
\end{tabular}


Table 13 continued

\begin{tabular}{|c|c|c|c|c|}
\hline & $\begin{array}{l}\text { (1) } \\
\text { Common events }\end{array}$ & $\begin{array}{l}\text { (2) } \\
\text { All, without ratings }\end{array}$ & $\begin{array}{l}\text { (3) } \\
\text { Ratings only }\end{array}$ & $\begin{array}{l}(4) \\
\text { All }\end{array}$ \\
\hline Stresstest & & $\begin{array}{l}0.006 \\
(0.077)\end{array}$ & & $\begin{array}{l}0.007 \\
(0.078)\end{array}$ \\
\hline Protests & & $\begin{array}{l}0.021 \\
(0.023)\end{array}$ & & $\begin{array}{l}0.022 \\
(0.023)\end{array}$ \\
\hline SMP & & $\begin{array}{l}-0.174 * * * \\
(0.045)\end{array}$ & & $\begin{array}{l}-0.174 * * * \\
(0.045)\end{array}$ \\
\hline LTRO & & $\begin{array}{l}-0.017 \\
(0.032)\end{array}$ & & $\begin{array}{l}-0.016 \\
(0.032)\end{array}$ \\
\hline OMT & & $\begin{array}{l}-0.268^{* * * *} \\
(0.044)\end{array}$ & & $\begin{array}{l}-0.267 * * * \\
(0.044)\end{array}$ \\
\hline Downgrading & & & $\begin{array}{l}0.018 * * \\
(0.009)\end{array}$ & $\begin{array}{l}0.019 * * \\
(0.009)\end{array}$ \\
\hline Constant & $\begin{array}{l}-0.001 \\
(0.002)\end{array}$ & $\begin{array}{l}-0.001 \\
(0.002)\end{array}$ & $\begin{array}{l}-0.001 \\
(0.002)\end{array}$ & $\begin{array}{l}-0.002 \\
(0.002)\end{array}$ \\
\hline Adj. $R^{2}$ & 0.003 & 0.030 & 0.002 & 0.032 \\
\hline Observations & 1741 & 1741 & 1741 & 1741 \\
\hline
\end{tabular}

Assistance, Austerity, and Forecast: events described in previous section; EDP: European Commission announcements of Excessive Deficit Procedures; Downgrading: change in official country ratings; Bankia: Bankia's request for a government bailout; Stresstest: announcement of European Banking Supervision stresstests; Protests: political protest activities against proposed austerity policies; SMP: start of the ECB's securities market program; LTRO: announcement of long-term refinancing operations by the ECB on December 8th 2011; OMT: first announcement of Outright Monetary Transactions program by the ECB on July 26th 2012; Downgrading: change in Spain's country rating. All event windows are set to 9,4 days before and after the event day, unless otherwise indicated

Robust standard errors in parentheses

$*$, **, *** Significance at the level of 10,5 and $1 \%$, respectively

Table 14 Event-dummy regressions: Portugal, 1/1/2007-9/3/2013

\begin{tabular}{|c|c|c|c|c|}
\hline & $\begin{array}{l}\text { (1) } \\
\text { Common events }\end{array}$ & $\begin{array}{l}\text { (2) } \\
\text { All, without ratings }\end{array}$ & $\begin{array}{l}\text { (3) } \\
\text { Ratings only }\end{array}$ & $\begin{array}{l}(4) \\
\text { All }\end{array}$ \\
\hline Assistance & $\begin{array}{l}-0.004 \\
(0.024)\end{array}$ & $\begin{array}{l}-0.002 \\
(0.027)\end{array}$ & & $\begin{array}{l}-0.001 \\
(0.027)\end{array}$ \\
\hline Austerity & $\begin{array}{l}0.018 \\
(0.033)\end{array}$ & $\begin{array}{l}0.042 \\
(0.033)\end{array}$ & & $\begin{array}{l}0.036 \\
(0.033)\end{array}$ \\
\hline Forecast & $\begin{array}{l}-0.004 \\
(0.013)\end{array}$ & $\begin{array}{l}0.011 \\
(0.012)\end{array}$ & & $\begin{array}{l}0.013 \\
(0.012)\end{array}$ \\
\hline EDP & & $\begin{array}{l}-0.031 \\
(0.145)\end{array}$ & & $\begin{array}{l}-0.027 \\
(0.143)\end{array}$ \\
\hline ESM & & $\begin{array}{l}-0.189 * * \\
(0.076)\end{array}$ & & $\begin{array}{l}-0.189 * * \\
(0.075)\end{array}$ \\
\hline
\end{tabular}


Table 14 continued

\begin{tabular}{|c|c|c|c|c|}
\hline & $\begin{array}{l}\text { (1) } \\
\text { Common events }\end{array}$ & $\begin{array}{l}\text { (2) } \\
\text { All, without ratings }\end{array}$ & $\begin{array}{l}\text { (3) } \\
\text { Ratings only }\end{array}$ & $\begin{array}{l}(4) \\
\text { All }\end{array}$ \\
\hline Troika & & $\begin{array}{l}0.030 \\
(0.033)\end{array}$ & & $\begin{array}{l}0.032 \\
(0.033)\end{array}$ \\
\hline SMP & & $\begin{array}{l}-0.548 * * * \\
(0.088)\end{array}$ & & $\begin{array}{l}-0.545 \\
(0.088)\end{array}$ \\
\hline LTRO & & $\begin{array}{l}0.009 \\
(0.059)\end{array}$ & & $\begin{array}{l}-0.022 \\
(0.059)\end{array}$ \\
\hline Protests & & $\begin{array}{l}-0.094 * * * \\
(0.032)\end{array}$ & & $\begin{array}{l}-0.092 * * * \\
(0.032)\end{array}$ \\
\hline OMT & & $\begin{array}{l}0.118 \\
(0.083)\end{array}$ & & $\begin{array}{l}0.120 \\
(0.083)\end{array}$ \\
\hline Downgrading & & & $\begin{array}{l}0.050 * * * \\
(0.017)\end{array}$ & $\begin{array}{l}0.050 * * * \\
(0.017)\end{array}$ \\
\hline Constant & $\begin{array}{l}0.002 \\
(0.004)\end{array}$ & $\begin{array}{l}0.002 \\
(0.004)\end{array}$ & $\begin{array}{l}-0.001 \\
(0.004)\end{array}$ & $\begin{array}{l}0.000 \\
(0.004)\end{array}$ \\
\hline Adj. $R^{2}$ & 0.002 & 0.034 & 0.005 & 0.044 \\
\hline Observations & 1741 & 1741 & 1741 & 1741 \\
\hline
\end{tabular}

Assistance, Austerity, and Forecast: events described in previous section; EDP: European Commission announcements of Excessive Deficit Procedures; Downgrading: change in official country ratings; Bankia: Bankia's request for a government bailout; Stresstest: announcement of European Banking Supervision stresstests; Protests: political protest activities against proposed austerity policies. SMP: start of the ECB's securities market program; LTRO: announcement of long-term refinancing operations by the ECB on December 8th 2011; OMT: first announcement of Outright Monetary Transactions program by the ECB on July 26th 2012; All event windows are set to 9, 4 days before and after the event day, unless otherwise indicated

Robust standard errors in parentheses

$*, * *, * * *$ Significance at the level of 10,5 and $1 \%$, respectively

\section{References}

Aizenman, J., Hutchison, M., \& Jinjarak, Y. (2013). What is the risk of European sovereign debt defaults? Fiscal space, CDS and market pricing of risk. Journal of International Money and Finance, 34(C), 37-59.

Attinasi, M. G., Checherita, C., \& Nickel, C. (2011). What explains the surge in euro area sovereign spreads during the financial crisis of 2007-2009? In R. W. Kolb (Ed.), Sovereign debt (pp. 407-414). Hoboken, New Jersey: Wiley.

Beber, A., Brandt, M. W., \& Kavajecz, K. A. (2009). Flight-to-quality or flight-to-liquidity? Evidence from the euro-area bond market. The Review of Financial Studies, 22(3), 925-957.

Beirne, J., \& Fratzscher, M. (2013). The pricing of sovereign risk and contagion during the European sovereign debt crisis. Journal of International Money and Finance, 34(C), 60-82.

Corsetti, G., \& Dedola, L. (2013). The mystery of the printing press: Self-fulfilling debt crises and monetary sovereignty. CEPR Discussion Paper 9358, Centre for Economic Policy Research, London.

De Grauwe, P. (2012). The governance of a fragile eurozone. Australian Economic Review, 45(3), 255-268.

De Grauwe, P., \& Ji, Y. (2013). Self-fulfilling crises in the eurozone: An empirical test. Journal of International Money and Finance, 34(C), 15-36. 
Gerlach, S., Schulz, A., \& Wolff, G. (2010). Bank and sovereign risk in the euro area. Discussion Paper Series 1: Economic Studies 09/2010, Deutsche Bundesbank.

Gibson, H. D., Hall, S. G., \& Tavlas, G. S. (2012). The greek financial crisis: Growing imbalances and sovereign spreads. Journal of International Money and Finance, 31(3), 498-516.

Johnston, J., \& DiNardo, J. (1997). Econometric methods (4th ed.). New York: McGraw-Hill.

MacKinley, C. (1997). Event studies in economics and finance. Journal of Economic Literature, 35(3), 13-39.

Meese, R. A., \& Rogoff, K. (1983). Empirical exchange rate models of the seventies: Do they fit out of sample? Journal of International Economics, 14(1-2), 3-24.

Steinkamp, S., \& Westermann, F. (2014). The role of creditor seniority in Europe's sovereign debt crisis. Economic Policy, 29(79), 495-552. 